\title{
TOXIC EFFECTS OF 2.5\% SODIUM HYPOCHLORITE, 17\% ETHYLENEDIAMINETETRAACETIC ACID, AND 2\% CHLORHEXIDINE SOLUTIONS ON THE VIABILITY OF DENTAL PULP MESENCHYMAL STEM CELLS
}

\author{
BUNGA CAHYA MUSTIKASARI, ANGGRAINI MARGONO*, KAMIZAR NAZAR \\ Department of Conservative Dentistry, Faculty of Dentistry, Universitas Indonesia, Jakarta, 10430, Indonesia. \\ Email: margonodewi@yahoo.com
}

Received: 27 August 2018, Revised and Accepted: 07 February 2019

\section{ABSTRACT}

Objective: Disinfection of the root canal system is a key factor in the success of regenerative endodontic treatment. However, dental irrigation solutions must exert bactericidal effects while maintaining stem cell viability. This study aimed to compare the effects of solutions containing $2.5 \%$ sodium hypochlorite, $17 \%$ ethylenediaminetetraacetic acid, and $2 \%$ chlorhexidine on the viability of dental pulp mesenchymal stem cells.

Methods: Primary cells were obtained from immature third molars and cultured. Subsequently, an immunofluorescence assay specific for the mesenchymal stem cell marker STRO-1 was used to identify dental pulp mesenchymal stem cells in the cultures. These cells were exposed to the three above-described solutions, after which cell viability was analyzed using an 3-(4,5-dimethylthiazol-2-yl)-2,5-diphenyltetrazolium bromide) assay.

Results: The viabilities of dental pulp mesenchymal stem cells treated with the three irrigating solutions differed significantly from the viability of control cells $(P \leq 0.05)$. However, no significant differences in cell viability were observed among the solutions $(P \geq 0.05)$.

Conclusion: All tested solutions had toxic effects on the viability of dental pulp mesenchymal stem cells.

Keywords: Dental pulp mesenchymal stem cell, Sodium hypochlorite 2.5\%, Ethylenediaminetetraacetic acid 17\%, Chlorhexidine 2\%, Cell viability.

(c) 2019 The Authors. Published by Innovare Academic Sciences Pvt Ltd. This is an open access article under the CC BY license (http://creativecommons. org/licenses/by/4. 0/) DOI: http://dx.doi.org/10.22159/ijap.2019.v11s1.162

\section{INTRODUCTION}

Ultimately, endodontic treatment aims to achieve biological healing through the regeneration of pulp tissue [1]. However, conventional endodontic treatments induce tissue repair through scar tissue formation or the use of biocompatible synthetic materials but do not restore the biological function and physical form of the damaged tissues [2,3].

Developments in biomolecular science and tissue engineering have ushered in a new era in the generation of human body tissues [4]. Accordingly, some studies have addressed the issues of endodontic tissue engineering and endodontic regeneration, a biological means of replacing damaged tissues such as dentin, root, and pulpodentinal complex. The goal of endodontic regeneration is to induce the formation of new tissues that are anatomically and functionally similar to the original tissues [5]. Various studies of endodontic regeneration revealed the successful regeneration of the pulpodentinal complex through tissue engineering methods [6].

In tissue engineering, stem cells play an important role because they have the ability to renew and differentiate into new cells in a typedependent manner; Gronthos et al. were the first to successfully isolate stem cells, and these efforts have been followed by many similar studies $[3,7]$. Although dental pulp stem cells (DPSCs) were initially isolated, adult teeth or extracted third molars are also important sources of stem cells that are morphologically similar to fibroblasts. Various studies have used primary cultured DPSCs, which remain highly proliferative even after several rounds of culture passage. DPSCs, which are self-renewing, form the pulp tissue, odontoblast, and ectopic dentin as well as reparative dentin and bone marrow tissues. Thus, DPSCs play an important role in endodontic regeneration [8-10].

Endodontic regeneration was initially performed in immature teeth containing necrotic pulp, wherein regeneration occurred through revascularization and development of the apex. Previously, immature teeth were treated through apexification and with calcium hydroxide. However, previous studies suggested that calcium hydroxide decreased the root strength by denaturing collagen [11]. Furthermore, apexification yielded incomplete root development and a thin dentin wall. Accordingly, the paradigm has recently begun to switch from apexification to tissue regeneration [11].

Some studies of endodontic regeneration have reported the greatest successes with revascularization of the pulp tissue. This treatment begins with root canal irrigation using minimal instrumentation, followed by disinfection with an antibiotic. Subsequently, bleeding into the root canal is triggered through over-instrumentation to induce a blood clot, which is expected to act as a scaffold to which stem cells from the apical papilla can adhere. Growth factors produced by platelets and the dentin walls are expected to facilitate the stem cell differentiation process [12].

Previous studies of endodontic regeneration have attributed success to the proper disinfection of the root canal [7], which should be achieved through instrumentation, irrigation of the root canal, or the use of root canal medications. According to van der Sluis et al. (2007), only $40 \%$ of the wall within the oval root canal makes contact with a rotational instrument [13]. Desai et al. (2009), Brito et al. (2009), and Howard et al. (2011) further confirmed that most of the root canal wall, particularly the apical third, does not make contact with dental instruments [14]. Therefore, the materials used for root canal irrigation play an important role in eliminating microorganisms, debris, and necrotic tissue. These materials should mainly exhibit antibacterial activity and have the capacity to dissolve organic tissues and debride the root canal without causing apical tissue toxicity $[1,15]$.

To optimize the endodontic regeneration process, irrigation materials must exertbactericidal activity while maintaining stem cell viability [16]. 
Sodium hypochlorite $(\mathrm{NaOCl})$ and ethylenediaminetetraacetic acid (EDTA) are currently widely used as irrigation materials, and various studies have compared their effects on stem cell viability. In a study by Trevino et al., a 17\% solution of EDTA yielded good results in terms of stem cell maintenance; by contrast, a $2 \%$ solution of chlorhexidine (CHX) exhibited stem cell toxicity in the absence of other living cells, and a $6 \%$ solution of $\mathrm{NaOCl}$ reduced the number of viable stem cells. At present, a $2.5 \%$ solution of $\mathrm{NaOCl}$ is widely used, and Walton and Rivera reported that $2.5 \%$ and $5.25 \%$ solutions of $\mathrm{NaOCl}$ are equally effective [17]. Therefore, $2.5 \% \mathrm{NaOCl}$ is currently used to retain the antibacterial properties while reducing toxicity. Still, further research is needed. This study aims to compare the effects of different methods and irrigation material concentrations on stem cell viability.

\section{METHODS}

For this in vitro study, all tools, materials, and reagents such as micropipettors, Schott bottles, and phosphate-buffered saline (PBS) were sterilized in an autoclave $\left(120^{\circ} \mathrm{C}, 20 \mathrm{~min}\right)$. All experimental procedures were performed within a biohazard cabinet. Dulbecco's modified Eagle's medium containing penicillin, streptomycin, and 20\% fetal bovine serum was used as the culture medium after filtration through a $50 \mathrm{ml}$ Sartorius Minisart single-use sterile syringe filter (pore size: $0.2 \mu \mathrm{m}$ ) and storage in a refrigerator.

Primary cells were isolated from a freshly extracted (within $24 \mathrm{~h}$ ) immature third molar that had been cleaned and immersed in $30 \mathrm{ml}$ of complete culture medium. The teeth were cleaved using a carborundum disc. Subsequently, pulp tissue was removed, cut into $2 \mathrm{~mm} \times 2 \mathrm{~mm}$ $\times 1 \mathrm{~mm}$ fragments, and incubated in petri dishes containing $0.25 \%$ trypsin for $5 \mathrm{~min}$. The dissociated cells were placed into 6 -well plates containing culture medium and incubated at $37^{\circ} \mathrm{C}$ temperature in an atmosphere of $5 \% \mathrm{CO}_{2}$ until they reached confluency. At that time, the medium was discarded, and the cells were washed with PBS, treated with $5 \mathrm{ml}$ of trypsin, and incubated at $37^{\circ} \mathrm{C}$ for $5 \mathrm{~min}$ to detach the cells. After inactivating the trypsin with $10 \mathrm{ml}$ of culture medium, the suspended cells were centrifuged in a $15 \mathrm{ml}$ tube at $1500 \mathrm{rpm}$ for $15 \mathrm{~min}$. The supernatant was discarded, and the cells were resuspended in a $25 \mathrm{ml}$ bottle containing culture medium. The resuspended cells were then plated in 96-well plates at a density of 5000 cells per well after counting the cells using a hemocytometer. The cells were incubated for $24 \mathrm{~h}$ at $37^{\circ} \mathrm{C}$ in an atmosphere of $5 \% \mathrm{CO}_{2}$

For the immunofluorescence assay, the cells were grown at a density of 5000 cells per chamber slide and incubated as described previously for 3 days. Subsequently, the medium was removed, and the cells were fixed in a solution of acetone and methanol solution for $2 \mathrm{~min}$. After fixation, the cells were washed thrice in PBS, with a final wash duration of 5 min. After drying, the prepared cells were treated with primary antibodies dissolved in PBS to concentrations of $100 \%, 50 \%$, and $25 \%$ (volume: $100 \mu \mathrm{l}$ per chamber) and at $37^{\circ} \mathrm{C}$ temperature for $60 \mathrm{~min}$ to allow antibody-antigen binding. Subsequently, the labeled cells were washed in PBS as described above and incubated with a fluorescein isothiocyanate-conjugated secondary antibody for $60 \mathrm{~min}$ at $37^{\circ} \mathrm{C}$. Finally, the labeled cells were washed in PBS, counterstained with Evans Blue dye, and rinsed with double-distilled water before observation with a fluorescence microscope.

In another experiment, the medium was removed from cultured cells and replaced with $100 \mu \mathrm{L}$ of each test solution. Three replications were set for each experimental condition. The cells were incubated as described above for $48 \mathrm{~h}$. After removing the medium from the culture plates, $100 \mu \mathrm{l}$ of 3-(4,5-dimethylthiazole-2-yl)-2,5-diphenyltetrazolium bromide) (MTT) was added to each well, followed by a $4 \mathrm{~h}$ incubation. This solution was removed, and any formazan crystals in the wells were dissolved with $70 \%$ ethanol. The optical density (OD) of each well was measured using a microplate reader at a wavelength of $595 \mathrm{~nm}$. To determine cell viability, the OD of each experimental group was normalized to that of the control group.
For the statistical analysis, a one-way analysis of variance was performed to evaluate differences between the control and the experimental groups. These values were presented with $95 \%$ confidence intervals.

\section{RESULTS}

In this study, we compared the effects of a $2.5 \% \mathrm{NaOCl}, 17 \%$ EDTA, and $2 \%$ CHX solution on cultured dental pulp mesenchymal stem cells. Initially, we performed an immunofluorescence assay specific for STRO-1, a mesenchymal stem cell marker, to ensure that dental pulp mesenchymal stem cells were used in our experiments. Representative microscopic images of immunofluorescence analyses are shown in Fig. 1.

The dental pulp mesenchymal stem cells were divided into two groups: the control and experimental groups. In the latter, dental pulp mesenchymal stem cells were exposed to solutions containing $2.5 \% \mathrm{NaOCl}, 17 \%$ EDTA, or $2 \%$ CHX. Fig. 2 presents a representative microscopic image of control-treated cells after a 2-day incubation.
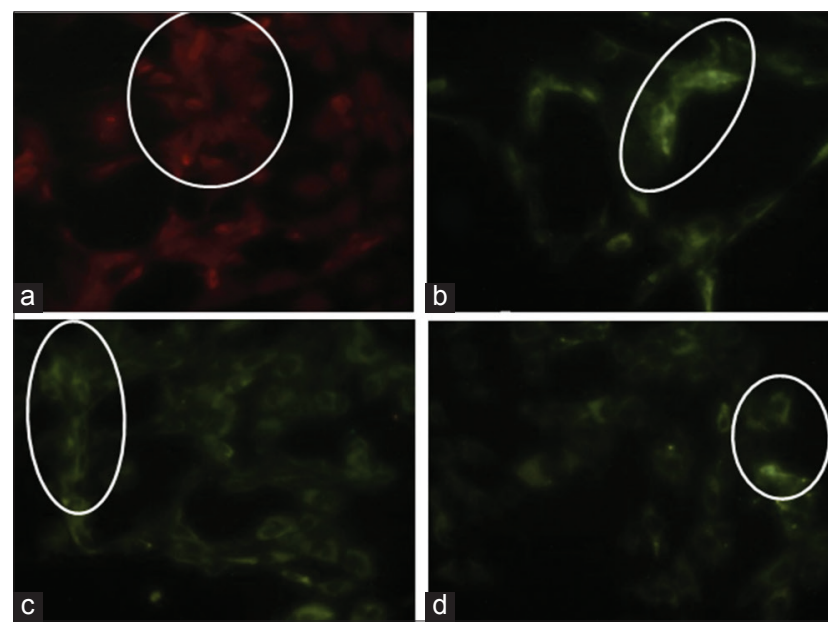

Fig. 1: Representative microscopic images of the immunofluorescence analysis of primary dental pulp mesenchymal stem cells. (a) Control group (no labeling with STRO-1 antibody), (b) Group I (undiluted primary antibody), (c) Group II (2x dilution of primary antibody), (d) Group III (4x dilution of primary antibody). The red color indicates no primary antibody labeling. The green areas indicate positive cytoplasmic STRO-1 antibody binding. The circle in (B) indicates a colony of cells

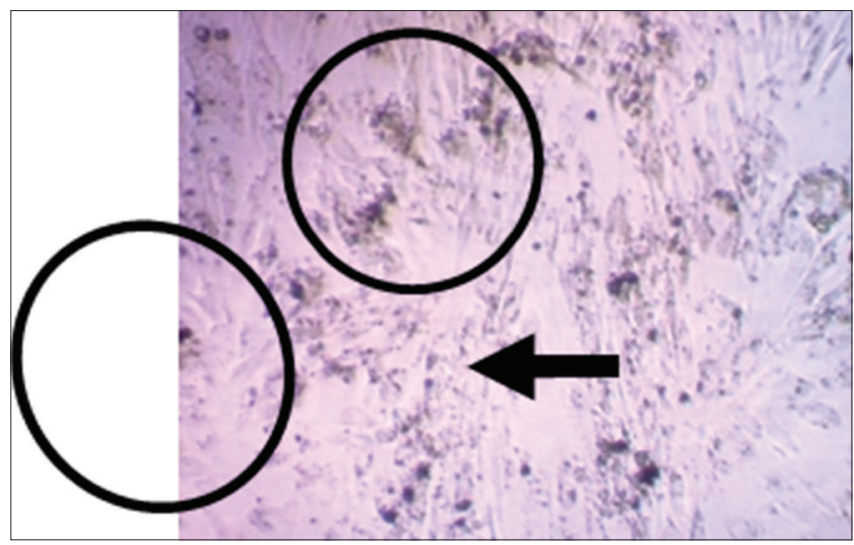

Fig. 2: Microscopic image of control-treated cells in medium after 2 days incubation $(\times 32)$. The circles indicate colonies of cells. The arrow indicates small dental pulp mesenchymal stem cells with a long, thin spindle shape 
Figs. 3-5 depict cells exposed to 2.5\% $\mathrm{NaOCl}, 17 \%$ EDTA, and 2\% CHX, respectively. Note that no viable cells remained after exposure to $2.5 \%$ $\mathrm{NaOCl}$ (Fig. 3), whereas viable cells were detectable in the cultures

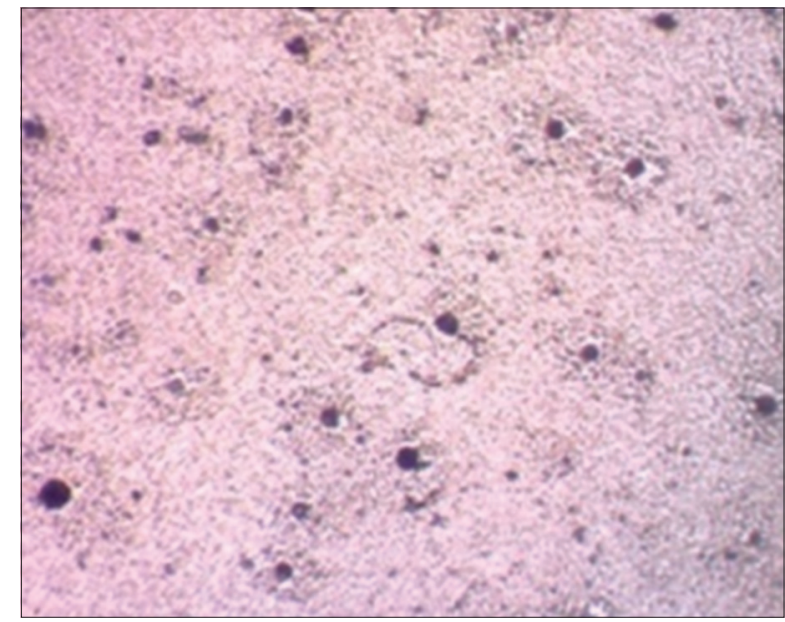

Fig. 3: Microscopic image of cells exposed to $2.5 \%$ sodium hypochlorite for 2 days $(\times 32)$

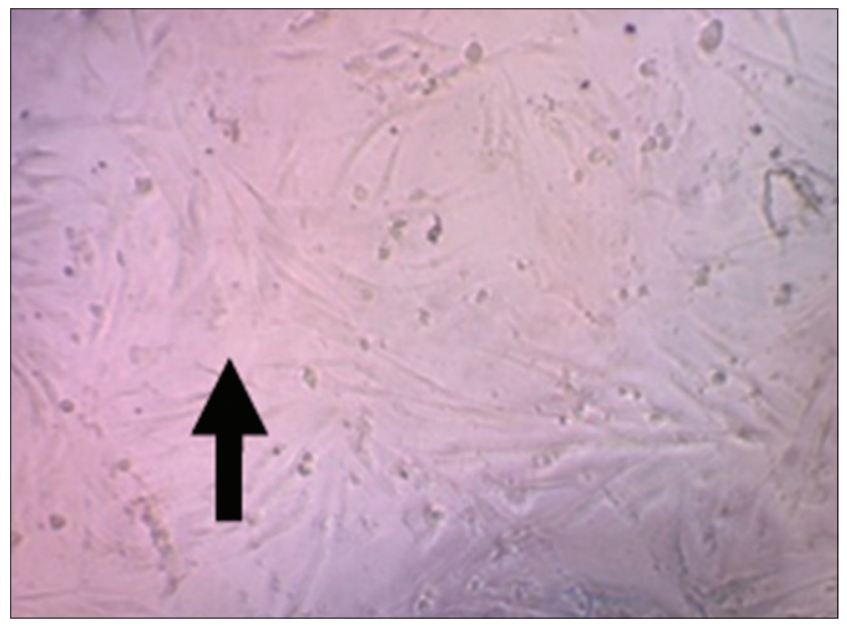

Fig. 4: Microscopic image of cells exposed to $17 \%$ ethylenediaminetetraacetic acid for 2 days $(\times 32)$. The arrow indicates a viable dental pulp mesenchymal stem cell

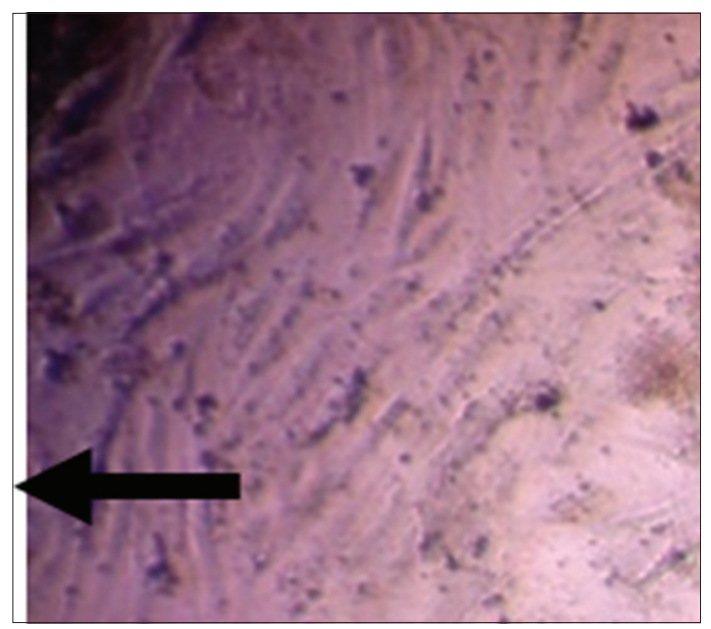

Fig. 5: Microscopic image of cells exposed to $2 \%$ chlorhexidine for 2 days ( $\times 32)$. The arrow indicates a viable dental pulp mesenchymal stem cell treated with the other irrigation solutions (Figs. 4 and 5). The average OD values, viability results, and significance analyses are listed in Table 1 according to the experimental irrigation solution. Notably, the highest viability rate was obtained for dental pulp mesenchymal stem cells exposed to a $2.5 \% \mathrm{NaOCl}$ solution (34\%), whereas the lowest was obtained for cells exposed to 17\% EDTA (22.3\%).

The results presented in Table 2 demonstrate that all irrigation solutions yielded significantly lower OD values relative to the control group $(P \leq 0.05)$. Table 3 , however, demonstrates the lack of statistically significant differences $(P \geq 0.05)$ in the OD values when comparing the $2.5 \% \mathrm{NaOCl}$ group with the $17 \%$ EDTA group $(\mathrm{p}=0.108)$ or the $2 \%$ CHX group ( $\mathrm{p}=1.000$ ) or the 17\% EDTA group with the $2 \%$ CHX group $(\mathrm{p}=0.183)$

\section{DISCUSSION}

As noted above, successful endodontic regeneration depends on the use of irrigation materials with bactericidal effects and minimal toxicity against stem cells [8]. In this study, we investigated the effects of three commonly used irrigation solutions on the viability of dental pulp mesenchymal stem cells harvested from extracted immature third molars. The third molar, which is frequently the last tooth to erupt, is normally extracted at an early stage of development and thus contains a significant population of dental pulp mesenchymal stem cells [18]. We selected primary cells for this study according to Perez et al. (2003), who deemed primary cells superior to secondary cells, although the former has a short life span and thus requires more sensitive handling [19].

Most previous endodontic regeneration studies have used apical papilla stem cells. However, according to Grontos et al. (2000), stem cells from the pulp are more proliferative in vitro compared with stem cells from the bone marrow and maintain this level of proliferation even after several culture passages. Stem cells taken from the immature third molar exhibit a high capacity for differentiation into actively migrating

Table 1: Average optical density values and cell viability rates in the control and experimental groups

\begin{tabular}{lllll}
\hline Solution & $\boldsymbol{n}$ & Mean OD \pm SD & Cell Viability \pm SD (\%) & p \\
\hline Control group & 3 & $0.103 \pm 0.007$ & $100 \pm 6.8$ & 0.000 \\
NaOCl 2.5\% & 3 & $0.035 \pm 0.002^{*}$ & $34 \pm 1.94^{*}$ & 0.000 \\
EDTA 17\% & 3 & $0.023 \pm 0.004$ & $22.3 \pm 3.88$ & 0.000 \\
CHX 2\% & 3 & $0.033 \pm 0.006$ & $32.04 \pm 5.83$ & 0.000 \\
\hline
\end{tabular}

OD: Optical density, SD: Standard deviation, CHX: Chlorhexidine,

EDTA: Ethylenediaminetetraacetic acid, NaOCl: Sodium hypochlorite

Table 2: Optical densities of the cells exposed to irrigation solutions relative to the control

\begin{tabular}{ll}
\hline Comparison & Significance of OD (p) \\
\hline Control versus. 2.5\% NaOCl & $0.000^{*}$ \\
Control versus. 17\% EDTA & $0.000^{*}$ \\
Control versus 2\% CHX & $0.000^{*}$ \\
\hline
\end{tabular}

${ }^{*}$ Comparisons of all three irrigation solutions with the control

yielded significant results. OD: Optical densities, CHX: Chlorhexidine,

EDTA: Ethylenediaminetetraacetic acid, NaOCl: Sodium hypochlorite

Table 3: Comparison of optical densities between irrigation solutions

\begin{tabular}{ll}
\hline Comparison & Significance of OD (p)* \\
\hline $2.5 \% \mathrm{NaOCl}$ versus 7\% EDTA & 0.108 \\
$2.5 \% \mathrm{NaOCl}$ versus 2\% CHX & 1.000 \\
$17 \%$ EDTA versus 2\% CHX & 0.183 \\
\hline
\end{tabular}

*No significant differences in ODs were observed between the

experimental groups. OD: Optical densities, CHX: Chlorhexidine,

EDTA: Ethylenediaminetetraacetic acid, $\mathrm{NaOCl}$ : Sodium hypochlorite 
and mineralizing odontoblasts. Although this molar contains a rich zone of cells within which stem cells in the pulp and the apical papilla are associated, both types of stem cells retain similar morphogenetic properties despite having different characteristics, and both are highly proliferative and capable of differentiating into odontoblasts. DPSCs are advantageous for sampling because they are present in greater numbers compared with stem cells from the apical papilla. In addition, the location of the latter stem cells carries a higher risk of contamination during tooth extraction $[6,20]$.

The monoclonal STRO-1-specific antibody was used in this study to identify a subpopulation of mesenchymal stem cells that share a similar morphology with fibroblasts in vitro. STRO-1 is a marker of osteogenic precursors in the human bone marrow stroma, as well as erythroid precursors $[10,21]$. We note that the STRO-1 antigen has not yet been classified, and thus, the research applications of this marker are limited. Although STRO-1 expression decreases over time in longterm cultures, this protein plays an important role in the migration and extracellular matrix adherence of mesenchymal stem cells [20]. Our immunofluorescence assay, which used an indirect technique that is tenfold more sensitive than the direct technique, demonstrated positive staining of the dental pulp mesenchymal stem cells by STRO-1 antibodies. Our technique was simple, featured a short procedure time (1-3 h), and demonstrated an important prognostic value [22].

We additionally used the MTT tetrazolium salt assay, which measures mitochondrial dehydrogenase activity, as a measure of cell viability. This assay is simple, safe, rapid, minimally toxic, easily repeatable, and widely used to evaluate cell viability and material cytotoxicity. In addition, the MTT assay is considered superior for determining the activity of mitochondrial dehydrogenase in living cells. As shown in our data tables, the viability of dental pulp mesenchymal stem cells decreased significantly in response to all tested irrigation solutions relative to controls.

Our finding that treatment with $2.5 \% \mathrm{NaOCl}$ decreased the viability of dental pulp mesenchymal stem cells relative to the control is consistent with previous reports by Alkahtani et al. and Longo et al. [23,24]. The previous research stated that $\mathrm{NaOCl}$ induced cellular damage and toxicity in bone marrow mesenchymal stem cells, whereas the latter group stated that $\mathrm{NaOCl}$ is cytotoxic to $\mathrm{KB}$ cells at high concentrations (2\%) and genotoxic (i.e., increase in micronuclei) at lower concentrations (1\%). This toxicity is attributed to the high level of hydroxyl ion activity, which affects the integrity of the cytoplasmic membrane. Specifically, $\mathrm{NaOCl}$ degrades the lipid structure of the membrane and inactivates proteins through saponification and chloroamination. In addition, the latter type of reaction produces free radicals such as hydroxyl ions that can inflict biological stress on different parts of the cell and damage cellular DNA, leading to chromosomal aberrations. Therefore, the observed differences in cell responses according to the $\mathrm{NaOCl}$ concentration can be attributed to the extent of exposure to free radicals, such that cells exposed to a high concentration would suffer damage during the first cell cycle, whereas cells exposed to lower concentrations would experience damage during DNA formation. Furthermore, the finding that $\mathrm{NaOCl}$ induced the smallest decrease in dental pulp mesenchymal stem cell viability among the tested solutions was consistent with previous findings [15]. The former group stated that $\mathrm{NaOCl}$ concentrations $<2.6 \%$ were less toxic than other irrigation materials, whereas the latter group stated that $3 \% \mathrm{NaOCl}$ was associated with relatively lower toxicity compared with 2\% CHX and MTAD.

We also found that EDTA reduced the viability of dental pulp mesenchymal stem cells relative to the control group. According to Alkahtani et al., EDTA-induced cytotoxicity is likely attributable to the chelating and acidifying effects of this chemical, consistent with the findings of Amaral et al. who determined that EDTA causes changes in the macrophage cell membrane through the chelation of ions such as $\mathrm{Ca}^{2+}$ and $\mathrm{Mg}^{2+}$ and thus accelerated cell apoptosis. In addition, EDTA can indirectly affect cell metabolism by reducing the cell nutrition and the $\mathrm{pH}$ of the culture medium, which both reduce cell viability $[24,25]$. However, our finding differed from that of Trevino et al. who stated that $17 \%$ EDTA yielded the best results in terms of cell viability and attachment [8]. This discrepancy may be attributable to different research methods, as Trevino et al. did not directly expose stem cells to an irrigation solution but rather performed endodontic and irrigation procedures in a simulated root canal system injected with apical papillary stem cells and examined the surviving cells under a microscope. In addition, the present study used an incubation time of $48 \mathrm{~h}$, which likely affected the toxicity of the solution. This would be consistent with the finding by Alkahtani et al. that EDTA-associated toxicity increases with the duration of exposure $[8,24]$.

Finally, we observed that CHX reduced the viability of dental pulp mesenchymal stem cells, which we attribute to its component with the cellular plasma membrane, which increases membrane permeability and leads to a loss of lysosomal enzymes. CHX cytotoxicity was also proposed by Lee et al., who stated that this chemical induces cytotoxicity by inhibiting collagen cell synthesis. Our results are also consistent with those of previous studies which claimed that CHX inhibits the synthesis of proteins and collagen in fibroblasts. CHX, which is highly cationic, affects the specific biosynthesis of proteins with inhibitory effects on cells. Therefore, the ability of CHX to inhibit cell growth, proliferation, and collagen synthesis may also cause it to inhibit tissue repair and regeneration $[24,26]$

Our microscopic assessment of cell morphology revealed differences among the treatment groups despite the lack of a significant difference in the viability assay. Cells exposed to $17 \%$ EDTA and $2 \%$ CHX exhibited lesser morphological changes compared with those treated with $2.5 \%$ $\mathrm{NaOCl}$. The former two groups had intact cell walls, indicating an early stage of cell apoptosis, whereas the cells in the latter group exhibited ruptured membranes or lysis indicative of necrosis. These findings are consistent with a study by Alkahtani et al. which found that although solutions of $\mathrm{NaOCl}$, EDTA, and CHX were all cytotoxic, the different compositions led to different cytotoxic effects. Specifically, cells exposed to $\mathrm{NaOCl}$ exhibited characteristics of cell necrosis, whereas those exposed to EDTA and CHX exhibited signs of apoptosis, a type of programmed cell death characterized by cell shrinkage, nuclear chromatin condensation, and nucleus fragmentation, although the plasma membranes remain intact and cytoplasmic organelles appear morphologically normal [24]. These results are consistent with our findings.

We note that the results of this purely cellular study cannot be compared directly with the findings of in vivo research and that this represents a limitation of our study. Because all experiments involved cultured cells, the results only represent the responses of isolated cells and do not consider host defense mechanisms for detoxification. In addition, the study was limited by an excessively long incubation time, which is not representative of clinical applications and thus enhanced the toxic effects. Therefore, further studies of both animals and humans are needed to evaluate the cytotoxicity and biocompatibility of all solutions in vivo.

\section{CONCLUSION}

Solutions containing 2.5\% NaOCl, 17\% EDTA, and 2\% CHX all had toxic effects on the viability of dental pulp mesenchymal stem cells. Notably, $2.5 \% \mathrm{NaOCl}$ and $17 \%$ EDTA induced the smallest and largest reductions in viability, respectively.

\section{CONFLICT OF INTEREST}

The author reports no conflict of interest.

\section{REFERENCES}

1. Haapsalo M, Qian W. Irrigants and intracanal medicaments. In: Ingle JI, Backland LK, Baumgartner JC, editors. Ingle's Endodontics 6. Connecticut: People's Medical Publishing House; 2008. p. 992-4. 
2. Hargreaves KM, Law AS. Regenerative endodontic. In: Hargreaves KM, Cohen S, editors. Cohen's Pathways of the Pulp. $10^{\text {th }}$ ed. St. Louis: Mosby Elsevier; 2011. p. 602-3.

3. Rosa V, Della Bona A, Cavalcanti BN, Nör JE. Tissue engineering: From research to dental clinics. Dent Mater 2012;28:341-8.

4. Bhat V, Prasad K, Bhat SS, Bhat A. Role of tissue engineering in dentistry. J Indian Acad Dent Spec 2011;2:37-42.

5. Hargreaves KM, Diogenes A, Teixeira FB. Treatment options: Biological basis of regenerative endodontic procedures. Pediatr Dent 2013;35:129-40.

6. Ruparel NB, Teixeira FB, Ferraz CC, Diogenes A. Direct effect of intracanal medicaments on survival of stem cells of the apical papilla. J Endod 2012;38:1372-5.

7. Gronthos S, Mankani M, Brahim J, Robey PG, Shi S. Postnatal human dental pulp stem cells (DPSCs) in vitro and in vivo. Proc Natl Acad Sci U S A 2000;97:13625-30.

8. Trevino EG, Patwardhan AN, Henry MA, Perry G, DybdalHargreaves N, Hargreaves KM, et al. Effect of irrigants on the survival of human stem cells of the apical papilla in a platelet-rich plasma scaffold in human root tips. J Endod 2011;37:1109-15.

9. Jamal M, Chogle S, Goodis H, Karam SM. Dental stem cells and their potential role in regenerative medicine. J Med Sci 2011;4:53-61.

10. d'Aquino R, De Rosa A, Laino G, Caruso F, Guida L, Rullo R, et al. Human dental pulp stem cells: From biology to clinical applications. J Exp Zool B Mol Dev Evol 2009;312B:408-15.

11. Mishra N, Narang I, Mittal N. Platelet-rich fibrin-mediated revitalization of immature necrotic tooth. Contemp Clin Dent 2013;4:412-5.

12. Nosrat A, Li KL, Vir K, Hicks ML, Fouad AF. Is pulp regeneration necessary for root maturation? J Endod 2013;39:1291-5.

13. van der Sluis LW, Versluis $M, W u$ MK, Wesselink PR. Passive ultrasonic irrigation of the root canal: A review of the literature. Int Endod J 2007;40:415-26.

14. Alkahtani A, Al Khudhairi TD, Anil S. A comparative study of the debridement efficacy and apical extrusion of dynamic and passive root canal irrigation systems. BMC Oral Health 2014;14:12.

15. Saghiri MA, Delvarani A, Mehrvarzfar P, Nikoo M, Lotfi M,
Karamifar K, et al. The impact of $\mathrm{pH}$ on cytotoxic effects of three root canal irrigants. Saudi Dent J 2011;23:149-52.

16. Galler KM, D'Souza RN, Federlin M, Cavender AC, Hartgerink JD, Hecker S, et al. Dentin conditioning codetermines cell fate in regenerative endodontics. J Endod 2011;37:1536-41.

17. Walton RE, Rivera EM. Cleaning and shaping. In: Walton RE, Torabinejad M, editors. Principles and Practice of Endodontics. $3^{\text {rd }}$ ed. United States of America: W. B Saunders Company; 2002. p. 219.

18. Atari M, Barajas M, Hernández-Alfaro F, Gil C, Fabregat M, Ferrés Padró E, et al. Isolation of pluripotent stem cells from human third molar dental pulp. Histol Histopathol 2011;26:1057-70.

19. Pérez AL, Spears R, Gutmann JL, Opperman LA. Osteoblasts and MG63 osteosarcoma cells behave differently when in contact with proRoot MTA and white MTA. Int Endod J 2003;36:564-70.

20. Estrela C, Alencar AH, Kitten GT, Vencio EF, Gava E. Mesenchymal stem cells in the dental tissues: Perspectives for tissue regeneration. Braz Dent J 2011;22:91-8.

21. Lovelace TW, Henry MA, Hargreaves KM, Diogenes A. Evaluation of the delivery of mesenchymal stem cells into the root canal space of necrotic immature teeth after clinical regenerative endodontic procedure. J Endod 2011;37:133-8

22. Premalatha BR, Rao RS, Mysorekar V. Immunofluorescence in oral pathology: Part I-methodology. World J Dent 2011;2:326-30.

23. Longo JP, Valois CA, Tapajós ÉC, Santos FM, Azevedo RB. Cytotoxicity and genotoxicity of endodontic irrigants on human cells. Rev Clín Pesq Odontol 2010;6:135-40.

24. Alkahtani A, Alkahtany SM, Mahmood A, Elsafadi MA, Aldahmash AM, Anil S, et al. Cytotoxicity of $\mathrm{QMix}^{\mathrm{TM}}$ endodontic irrigating solution on human bone marrow mesenchymal stem cells. BMC Oral Health 2014;14:27.

25. Amaral KF, Rogero MM, Fock RA, Borelli P, Gavini G. Cytotoxicity analysis of EDTA and citric acid applied on murine resident macrophages culture. Int Endod J 2007;40:338-43.

26. Lee TH, Hu CC, Lee SS, Chou MY, Chang YC. Cytotoxicity of chlorhexidine on human osteoblastic cells is related to intracellular glutathione levels. Int Endod J 2010;43:430-5. 